\title{
Integrating Climate Change into the Environmental Assessment Process: What is the Situation in African Francophone Countries?
}

\author{
Tchindjang Mesmin \\ Geography Department, University of Yaoundé I, Cameroon
}

Copyright $(2018$ by authors, all rights reserved. Authors agree that this article remains permanently open access under the terms of the Creative Commons Attribution License 4.0 International License

\begin{abstract}
Climate change (CC) in the form of planetary warming has many negative impacts on the development of many countries. Since the ratification of the United Nations Convention on Climate Change (UNFCCC), most African Francophone countries have recently incorporated climate change in their planning process done by environmental assessment (EA) or not. EA is a process of estimating and evaluating significant short-term and long-term effects of a program or project on the quality of its location's environment. It also includes identifying ways to minimize, mitigate, or eliminate these effects and compensate their impacts. The aims of this paper is to present the existing level of integration of situation of $\mathrm{CC}$ in EA. As part of a literature review, pertinent documents were assessed accompanied by fieldwork related to the COMDEKS (Community Development knowledge for Satoyama Initiative), studies of population vulnerability and resilience linked to climate change in the region and particularly in Cameroon, CAR, Gabon and Togo. Results show that in sub-Saharan Africa in particular, various strategies have employed environmental assessment techniques, including a participatory approach in developing policies, plans and programs. Climate change "proofings" developed by GIZ helped some countries to adopt appropriate practices. This approach consisted of a review of a particular system or entity vis-à-vis its ability to cope with the climate change to which it is likely to be confronted. Resulting measures have affected various sectors, including agriculture, forestry, and energy (i.e., the GHC emission sectors).
\end{abstract}

Keywords African Francophone Countries, Agriculture, Climate Change, Energy, Environmental Assessment

\section{Introduction}

Environmental assessment is a process of estimating and evaluating significant short-term and long-term effects of a program or project on the quality of its location's environment. It also includes identifying ways to minimize, mitigate, or eliminate these effects and/or compensate for their impact. An environmental assessment is a results-based process used by the developing countries Governments to understand and evaluate the potential environmental impacts of many projects before any irreversible decisions are taken that may lead to negative effects on the environment, natural resources or public health and safety.

Climatic change is perhaps one the most complex problems the entire world has been facing this last century. Even on it definition, the agreement is so far to be reached in the climate science literature. In fact, a clear and thorough conceptual analysis of the concept and different definitions clarifying their benefit and disadvantages is still missing [1].

The climate is an aggregate of weather conditions distributing variables known as climate variables arising from a specific configuration of the climate system. In such a context, consensus deserves more attention like hitherto [2]. "Climate change" means a change of climate attributed directly or indirectly to human activities altering the composition of the global atmosphere associated to natural climate variability observed over comparable time periods [3].

Therefore, climate change is a change in the typical or average weather at the level of a city, a region, a country or worldwide. This could be viewed in average annual rainfall, temperature and humidity for a given month or season. 
Considering the characterisation of climate from the IPCC report, Climate in a narrow sense is usually defined as the average weather, or more rigorously, as the statistical description in terms of mean and variability of relevant quantities over a time period ranging from months to thousands or millions of years. It has been agree from the World Meteorological Organization acronym (WMO) that the classical period for averaging these variables is 30 years, as defined by the WMO. The relevant quantities are most often surface variables such as temperature, precipitation and wind. In a wider sense, Climate is the state, including a statistical description, of the climate system [4 \& 5].

On the other hand, it has been demonstrated that Earth's climate is always changing. In the past, Earth's climate has gone through warmer and cooler periods, each lasting thousands of years. Some causes of climate change are natural. These include changes in Earth's orbit and in the amount of energy coming from the sun. Ocean changes and volcanic eruptions are also natural causes of climate change. While some scientists think that recent warming can't be explained by nature alone, others are convinced that since the mid-1900s, the global warming results from human activities including the burning of coal, oil and gas and other multiplying heat-trapping greenhouse gases, such as carbon dioxide, into the air.

\section{Climate Change in Sub-Saharan Africa (SSA)}

World scientific community has conduct studies on the climate variability and change among which one can identify the African drought of 1972-1973 and 1983-1984. Centred on tropical Sahelian zone, the consequences were: decreased rainfall, lower groundwater levels, stream flows drop of water [6 \& 7]. Findings of the World Meteorological Organization (WMO) and the IPCC reports indicate a warming situation of about $0.7 \mathrm{C}$ for almost the entire African continent during the twentieth century.

In SSA, climate has experienced alternating wet and dry periods in response to global climate change at all time scales. According to the Inter-governmental Panel on Climate Change (IPCC), African continent appear to be highly vulnerable to climate change [8 \& 9]. It hosted a fast growing population (nearby 1 billion in 2010) and a wide ecosystems diversity ranging from tropical evergreen forests to savannas, grasslands and desert. The diverse climate regimes associated with these ecosystems are subject to large inter-annual, inter-decadal and multi-decadal variations, particularly with regard to rainfall $[10 \& 11]$. Africa also has a very sparse observational and inconsistent network [8 \& 9].

As precise by Tchindjang et al, [12], palaeo records show an increase in environmental aridity since about $3 \mathrm{Ma}$, punctuated by intervals of phenomenon amplification, of steps development synchronous and amplification of high-latitude glacial cycles. In East Africa, the pollen data recorded by Bonnefille [13 \& 14] highlight the cooling marked from 3.3 Ma to $2.5 \mathrm{Ma}$. A spectacular manifestation of climate change is the presence of a wet and green Sahara during the lower and Middle Holocene indicating a migration to the north of the tropical rainfall belts.

Also, severe weather historical events reported in Africa in time at scales less than 1000 years are often associated with imbalances climatic system affecting large parts of the World [15-18]. Whatever the time scale, the oscillations wet / dry identified in tropical Africa during the Plio-Quaternary appear associated with profound changes in the global climate system or regional dynamics exchanges between the atmosphere, ocean and biosphere. In central African and Congo Basin countries, several authors [19-24] show evident fluctuations on floods occurrence and rainfall variations whose most obvious manifestations are observed at the seasonal scale.

\section{What are the Impacts of Earth's Warming Climate?}

The fifth Intergovernmental Panel on Climate Change (IPCC) report [4]. states with 95 percent confidence that humans are the main cause of the current global warming ${ }^{1}$. According to UNFCCC [3], "Adverse effects of climate change" means changes in the physical environment or biota resulting from climate change which have significant deleterious effects on the composition, resilience or productivity of natural and managed ecosystems or on the operation of socio-economic systems or on human health and welfare. Some of these impacts are now a reality. For instance, sea levels are rising while snow and ice cover are decreasing. Rainfall patterns and growing seasons are changing. Further sea-level rise and melting of snow and ice are likely as Earth warms. The warming climate likely will cause more floods, droughts and heat waves. The heat waves may get hotter, and hurricanes may get stronger.

To assess and address the impacts of these changes, tools built up by environmental impacts science need to be applied to specific projects or domains of climate change. Environmental assessment or environmental evaluation are diverse, ranging from Environmental impact assessment, Environmental strategic assessment (ESA), Environmental audit (EA) and environmental management system (EMAS) to life cycle analysis (LCA). Among these series, Environmental Impact Assessment (EIA), Environmental audit and recently environmental strategic assessment are mostly used in African francophone countries.

Detailed study based on environmental assessment (EA) determines the type and level of effects an existing facility or a proposed project would have, on its natural environment. Its objectives include (1) Identify possible environmental effects, (2) help decide whether the effects

\footnotetext{
${ }^{11}$ It is extremely likelv 195 percent confidencel more than half of the observed increase in global average surface temperature from 1951 to 2010 was caused bv the anthropogenic increase in greenhouse gas concentrations and other anthropogenic forcings together
} 
are acceptable or not to see if there are specific actions to be taken to reduce them for continuation of the proposed project, (3) to propose, design/implement appropriate monitoring, mitigation, and management measures, (4) propose measurements to mitigate adverse effects and to enhance positive effects, (5) design/implement appropriate monitoring, mitigation, and management measures, (6) Predict whether there will be significant adverse environmental effects, even after the mitigation is implemented, (7) propose acceptable alternatives, and (8) lastly prepare an environmental impact report (EIR). The adequacy of an EIA is based on the extent to which the environmental impacts can be identified, evaluated, and mitigated $^{2}$.

In 2009, due to many disasters recorded within the world, the SIFEE colloquium held in Niamey focused on Climate change and environmental assessment: stakes and tools for impacts assessment and adaptation plans ${ }^{3}$. It means how the practitioners should integrate the climate change or its effects when dealing with EA processes. In 2017, the IAIA colloquium held in Montreal ${ }^{4}$ raised-up the assessment of this integration within the World countries and this article focused on the situation of French speaking countries of Africa. Most of these countries are developing countries and least developed countries (LDCs).

Nowadays, it is known that climate change (CC) creates negative and perverse impacts requiring appropriate action. However, populations and productive systems in many developing countries are highly dependent on natural resources and often have a limited adaptive capacity. Rainfed agriculture in these countries is more dependent on the climate. As a result, they are often among those most affected by climate change. While the need for action has been clearly recognized by the entire development community, the debate on how to integrate climate change into the development practices and initiatives is still going on. Environmental assessment (EA) thus appears as a tool for integrating climate change into the decision-making process. Indeed, the impacts of global warming on territories, resources and lifestyles are unprecedented and still poorly controlled. Least developed countries, developing countries and small island states are the most affected with the increase of natural risks and disasters, water stress, desertification, rainfall modification.

In the francophone countries of sub-Saharan Africa (SSA), the situation is quite complex, because of many

\footnotetext{
${ }^{2}$ Read more:

http://www.businessdictionary.com/definition/environmental-impact-asse ssment-EIA.html

${ }^{3}$ Changements climatiaues et évaluation environnementale : enieux et outils pour l'évaluation des impacts et l'élaboration de plans d'adaptation http://www.sifee.org/ressources/actes-des-colloques/actes-du-colloque-in ternational-de-niamey

${ }^{4}$ Environmental assessment (EA) processes as a tool to integrate the climate change in decision making, methodological challenges integrating climate change into the EA processes, leading examples of integration of climate change into the EA processes for practitioners.
}

bottlenecks and impediments in integrating issue of climate change in the EA processes, among which: (1) Poor knowledge on the topic and uncertainty about the local impacts of CC; (2) The thorny problem of funding for adaptation (insignificant in agricultural domain); (3) The fuzzy limit between development and adaptation; (4) The difficulty of analyzing vulnerability and adaptive capacity locally; (5) The real control of EA processes itself by governments and NGOs.

Thus, there is a dilemma because developers resisted and argued that EA/EIA is against development because laws and policies supporting it dictated that lands developments causing massive adverse impacts should be halted and riparian affected population compensated. In a nutshell, EA is considered just another bureaucratic stumbling block in the path of development. Secondly, it is conceived as a sinister means by which industrialized nations intend to keep developing countries from breaking the vicious cycle of poverty. Thirdly, the experts in the developing countries were foreigners who were viewed as colonization agents. However, financial institutions and donors have include EA process among the loan conditions. Consequently, the need for EAs is increasingly important, becoming a statutory requirement in many developing countries [25].

\section{Methodology}

\subsection{Documents Consultation}

Various reports and strategic documents on climate change and environmental impacts assessment in sub-Saharan African countries have been consulted. Most of the documents on $\mathrm{CC}$ have been published under the framework and provisions of UNFCCC and IPCC. Most of the reports on second communications on climate change of sub-Saharan African countries (SSAC) were consulted (Cameroon, Gabon, Benin, Burkina Faso, Mali, Ivory Coast, Niger, Central African Republic (CAR), Congo, Togo, Burundi, etc.). Also all documents dealing with adaptation in SSAC benefited from my attention being National Adaptation Program of Action (NAPAs) from CAR, Benin, Burundi, Gabon, Niger; National Adaptation Plan for Climate Change (NAPCC) from Cameroon and Ivory Coast and Nationally Appropriate Mitigation Actions (NAMAs), of all those countries. Information leaflets done by $\operatorname{CSC}^{5}[24]$ on climate change scenarios of the Congo Basin countries were part of the consulted documents. At

\footnotetext{
5 "Climate Change Scenarios in the Congo Basin" project was implemented by GIZ. Scientific component was realize by Climate Service Center (CSC- Germany) and Wageningen University Research (WUR) with an interdisciplinary workflow. It links projected climate change and its impacts on hydrography, forests and agriculture. Three global climate models used are ECHAM5 / MPIOM, CNRM-CM3 and IPSL-CM4. The scenarios issued have the advantage of illustrating long-term changes in climatic parameters such as temperature and rainfall.
} 
least, the author read and exchange with experts on the EA process of these countries between 2006 and 2010 workshops organized in Cameroon under the framework of Institut de la Francophonie pour le Développement durable (IFDD) ${ }^{6}$. This literature was completed by findings from many consultancies, workshops and capacity building on EA and climate change in Cameroon and African countries. The author also took advantage from his experience as a member of the task force on collecting data and finalizing NAPCC, second communication reports and INDC (all in 2015) in Cameroon.

\subsection{Fieldworks Linked with Consultancies}

The author has been a consultant on many tender documents on Environmental impacts assessments/environmental audits since 2008 on various field (road construction, social welfare, mining activities and deforestation, oil palm farms and deforestation). As Principal investigator (PI), he led various field surveys on climate change and related vulnerabilities implemented between 2012 and 2015, using EA participative methods. Under the UNDP-COMDEKS framework, the landscape resilience tools (socio ecological production landscapeSEPL tools) were used to assess and build local population mitigation strategies in the Far North (being a Sahelian zone) of Cameroon in 2013 and 2016. SEPLs tools were collaboratively developed under the leadership of the International Partnership for the Satoyama Initiative. They are used as indicators resilience in the target landscapes [26] and measured by twenty questions split in four interrelated dimensions, namely: 1) ecosystem protection and biodiversity conservation; 2) agricultural biodiversity; 3) knowledge, learning, and innovation; and 4) social equity and infrastructure. Each participant is invited to provide independent scores on a scale of numbers integers from 1 to 5 (i.e. no number being negative), [26-27]. All these cumulative experiences have been capitalized in the writing of this paper. The results are organized around one theoretical and four practical situations.

\section{Results}

\subsection{EA and CC Theoretical Practices in Sub-Saharan African Development Planning Strategies, Documents and Reports}

Theoretically, the EA practitioner should carry out an in-depth analysis of the CC's impacts range and determine the level of confidence that may be attributed to the data [28]. Also, integrating climate change considerations into EA can help determining the project's compliance with greenhouse gas (GHG) measures, including national

\footnotetext{
${ }^{6}$ French Institute for Sustainable Development.
}

adaptation and government plans on Climate Change. Integration can help proponents adopting best practices that promote and facilitate CC adaptation, including changes in the frequency and intensity of extreme weather events, average temperature rises and changes in rainfall patterns. However, despite the expected massive reduction of GHG emissions in the near future, changes in climate conditions will continue to occur and the extent of its impacts will increase significantly in the future. For this reason, this paper will emphasize on three main practical issues.

Since the ratification of the United Nations Convention on Climate Change (UNFCCC), most African French-speaking countries have tied to the international evolution of the global climate situation, it can be seen from several documents on Climate Change. Those countries used environmental assessment methods and tools, including a participatory approach in writing and disseminating policies and planning documents, namely:

I). Vision 2020, 2025 or 2035: these are important national planning and development documents issued by each country. Such documents should be extended to economic growth strategies and plans as well as national action plans to fight against desertification (PAN-LCD/NAP-FAD).

II). Second national climate change communications (SNCC), National Adaptation Program of Action (NAPAs), National Adaptation Plan for Climate Change (NAPCC), Nationally Appropriate Mitigation Actions (NAMAs), Reducing emissions due to deforestation and forest degradation (REDD+), Monitoring - Reporting - Verification (MRV) and Intended Nationally Determined Contributions (INDC). These reports are based on GHG emissions, climatic risk and vulnerabilities.

It is worth mentioning that the above strategic documents are drawn up through a broad vertical and horizontal consultation (bottom-up and top-down). Its cover key vulnerable sectors (agriculture, water, coastal areas or health) and on cross-cutting issues on $\mathrm{CC}$, including adaptation and mitigation measures. Its validation is consecutive to public participation (local population, donors, NGO, Governments and stakeholders). The next example is provided by German technical cooperation tool.

\subsection{EA and CC : Case Study of Climate Proofing for Development of the GIZ (German Technical Cooperation)}

"Climate Proofing for Development" (CPDev) is a tool built by German development cooperation (GIZ), and designed to support the integration of Climate Change impacts and reducing its risks [29]. It is a methodological approach that aims at incorporating $\mathrm{CC}$ issues into development planning; raising awareness of the $\mathrm{CC}$ challenges and opportunities as well as more effective and 
resilient measures.

The tools started by project screening before extended to options practices that are common in environmental assessment. This explain why CPDev can be used at different levels, being national (cross-sectoral policies, development plans, budget), sectoral (policies, strategies, investments programs), local (municipal plans, land-use planning) and project or programs level. As for EA, CPDev appears to be a multiusers tool involving stakeholders, public authorities, national and international organizations, donors, NGOs, associations and private sector. The following paragraphs describe two cases related to the CPDev field application: adaptation in agriculture and mitigation in energy sector.

\subsubsection{Climate Proofing Application to Agriculture in Sub-Saharan African Countries}

SSA countries practice rain fed agriculture which is vulnerable to Climate change. Due to poor climate finance, African agriculture is the less responsible for Climate change while being the most vulnerable and the most impacted [30]. CPDev was successfully applied in agriculture in Morocco, Mali, Togo and Burkina Faso using EA approach with four main steps: (1) analysis of the impacts of climate change on the project; (2) development of adaptation options; (3) prioritization of adaptation options; (4) integrating the results to the project design.

For example, in the humid and subhumid agricultural areas (Togo, Cameroon), excessive rainfall lead to the proliferation of insect pests such as mirids and the emergence of plant diseases like the necrotic decay of the coffee tree, the swollen shoot and the brown rot for the cocoa [31]. It attacks the root system of plants, leading to the wilting of these crops. In the dry regions of SSA (Mali, Senegal, Burkina Faso, Northern Cameroon), cereals (maize, millet and sorghum specifically) are particularly vulnerable (Figure 1) due to their high sensitivity to water stress, resulting in productivity decline and reduction in food supply. Such a situation leads to the surge in prices and food starvation/insecurity. Also soils are dried and animals die from severe drought and lack of water in many ponds (Figures $2 \mathrm{a} \& \mathrm{~b}$ ). The above results give way to issue a CPDev manual / guide for Sustainable Land Management projects and programs in those countries.

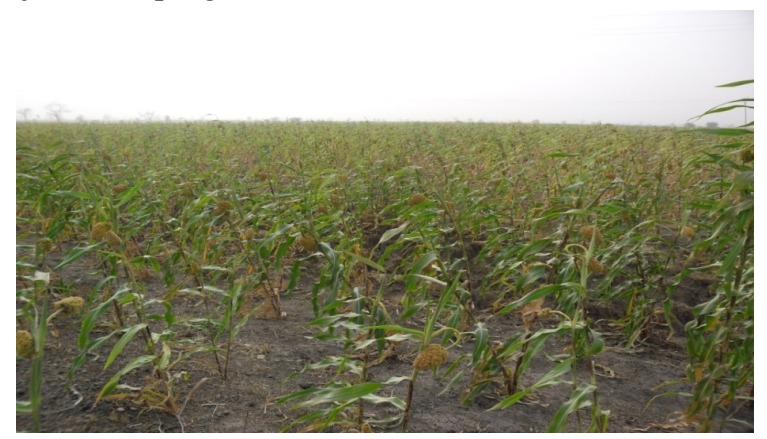

Figure 1. Heat pocket and drying out of millet in the Sahel (Maroua, 2012)

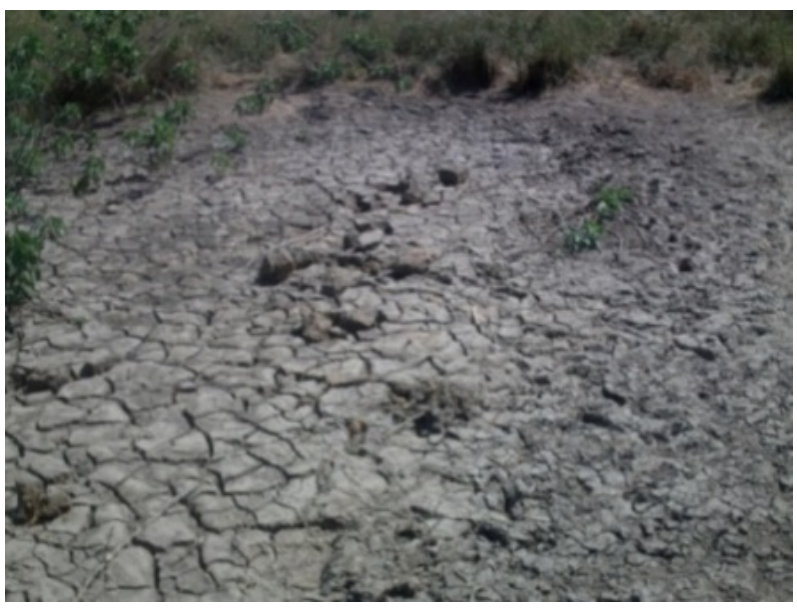

Figure 2a. Severe drought and soil destruction

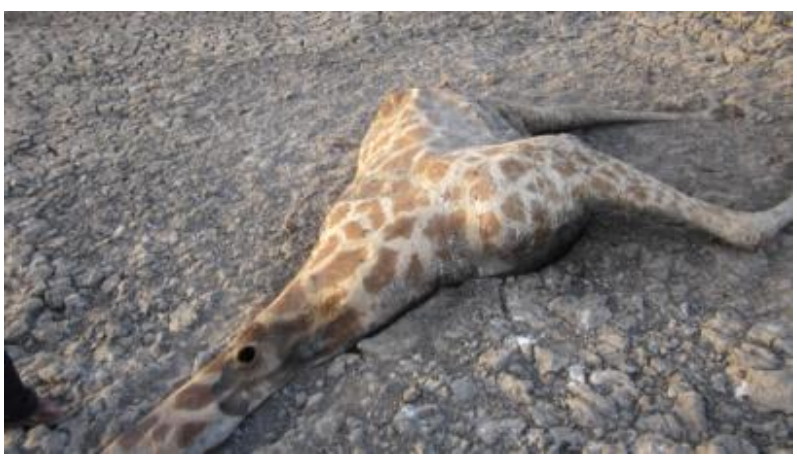

Figure 2b. Animal deaths in the Sahel - Waza National Park (fieldwork, 2012)

\subsubsection{Climate Proofing Application to Energy Sector in Developing Countries}

According to Maurice Strong ${ }^{7}$, we must treat climate as a security issue, the most important threat to global security we will ever face. Energy is at the heart of this transition. Climate security and energy security are two sides of the same coin: one cannot be achieved without the other." Food security matches with energy availability. Energy sector representing the major producer of Greenhouse emissions through fossil fuel combustion, is also vulnerable to climate change impacts. Given the inextricable link between socio-economic development and access to energy, it is clear that any approach of securing development in the context of a changing climate must consider the adaptation needs of the energy sector. Weak energy systems constrain efforts to reach the sustainable development goals. For instance, energy is essential in reducing disease and consequences. Clean energy (solar, biomass, biogas) can reduce SSA traditional wood burning and related respiratory deadly diseases as described by WHO [32].

It is also known that changes in temperature affects both

${ }^{7}$ Maurice Strong is the former Secretary General of the UN Conferences Stockholm (1972) and Rio (1992). 
biomass growth and distribution which impact quantity and quality of animal fodder and crops, material for human shelter, heating, fuel agriculture, electricity generation, health and sanitation. Also, changes in rainfall patterns influence agriculture, electricity generation, health and sanitation. Given the clean and efficient energy's role in economic development, it is crucial to reduce energy system vulnerability while increasing system resilience. In this light, HELIO international [25] developed a straightforward methodology with a set of indicators to assess the vulnerability and resilience of national-level energy systems to climate change via EA tools and CPDev. HELIO succeeded in identifying policies and measures able to support adaptation activities. After analyzing energy problems within 10 SSA countries (Benin, Burkina Faso, Cameroon, D.R. Congo, Kenya, Mali, Nigeria, Senegal, Tanzania, Uganda) in four domains (Hydropower, biomass, Wind and solar energy), HELIO concludes that these countries are directly impacted by changes in rainfall and temperature level. Such a situation justifies adaptation and mitigation measures.

Adaptation measures can be categorized into infrastructural/technical and behavioral/social responses [33]:

I). Technical adaptation tries to make infrastructures less vulnerable against long-term changes in meteorological variables and extreme events.

II). Behavioural adaptation adjusts the operation of the infrastructure (both existing and new) and the siting of new infrastructures to minimize damages.

Overall, HELIO International report summarizes anticipated climate-induced impacts on key energy systems and outlines possible adaptation measures, proposing eight recommendations to help reinforcing the resilience of energy systems [33]:.

1) Systematically assess and monitor energy systems to ensure that they are robust enough to adapt to anticipated climate-related impacts.

2) Expand the current assessment process for new energy systems (solar, biogas, etc.).

3) Develop a medium to long-term strategy to move toward a safer, decentralized, low-carbon energy supply system.

4) Implement energy demand management as an adaptation measures.

5) Cultivate in-countries capacity to evaluate and respond to energy needs from a climate perspective.

6) Invest in ecosystem services that support existing and planned energy production.

7) Establish transparent technology transfer and financing procedures.

8) Develop participatory energy governance to cultivate first-hand knowledge of energy needs while mobilizing vital support from beneficiaries

\subsection{EA, Climate Change and Green Sahel Operation (Cameroon)}

In the Northern Cameroon cities, (Garoua and Maroua), firewood is frequently used by the population for household purposes. More than $94 \%$ households use firewood, $90 \%$ charcoal and $64 \%$, wood. Wood consumption is more than twelve times the amount of gas used by households with an average, of $2-3 \mathrm{~kg} /$ day individual wood requirement per inhabitant [34]. The anarchical way of collecting firewood leads to huge pressure on this resource.

This situation has brought the Cameroon government to relaunch the Green Sahel Operation in this environmentally sensitive dry region characterized by poor farming practices and overgrazing [12]. Indeed, multidisciplinary studies have attempted to recover the production capacity of "hardés" (indurated sterile soil). After an environmental audit of the former projects, more than $80 \%$ of the population was sensitized through awareness campaigns in the implementation and monitoring of the afforestation program to stop the progression of the desert. The program consists of removing the first $50 \mathrm{~cm}$ of the soils (which are battleships) and establishing the agroforestry nursery. This participative project using EA methods aims at preventing and reducing the semi-arid and dry lands degradation, and then restoring degraded soils. It also contributes to restore and improve the fertility of degraded and marginal lands, to strengthen this sahelian vegetation cover, to discourage the firewood cutting. Finally, the project distributes improved cooking stoves to replace fossil energy and reduced burden of firewood to stakeholders and raises public awareness against desertification.

As findings, there was a return of wildlife and a revival of economic activities related to Non-Timber Forest Products (NTFPs). The remaining problems to solve were bush fires, vandalism, deferred grazing, nocturnal pasture and the lack of species signaling on different sites. Among the diverse approaches, the afforestation (Figure 3) project described sounds like the best adaptative approach in fighting against desertification. It is best to advise participating farmers who received plants for agroforestry and forest management in the agricultural and pastoral areas. Afforestation, coupled with the distribution of improved stoves among the local population, has momentarily solved the problem of fuel wood in this area [12]. In addition, afforestation is the most appropriate response, the most manageable and effective improvement to climate change and climate risks. Thus, it appeared to be the most effective response incorporating complementary processes such as water conservation, soil retention, reducing the runoff, fighting against wind erosion and bush fires. 


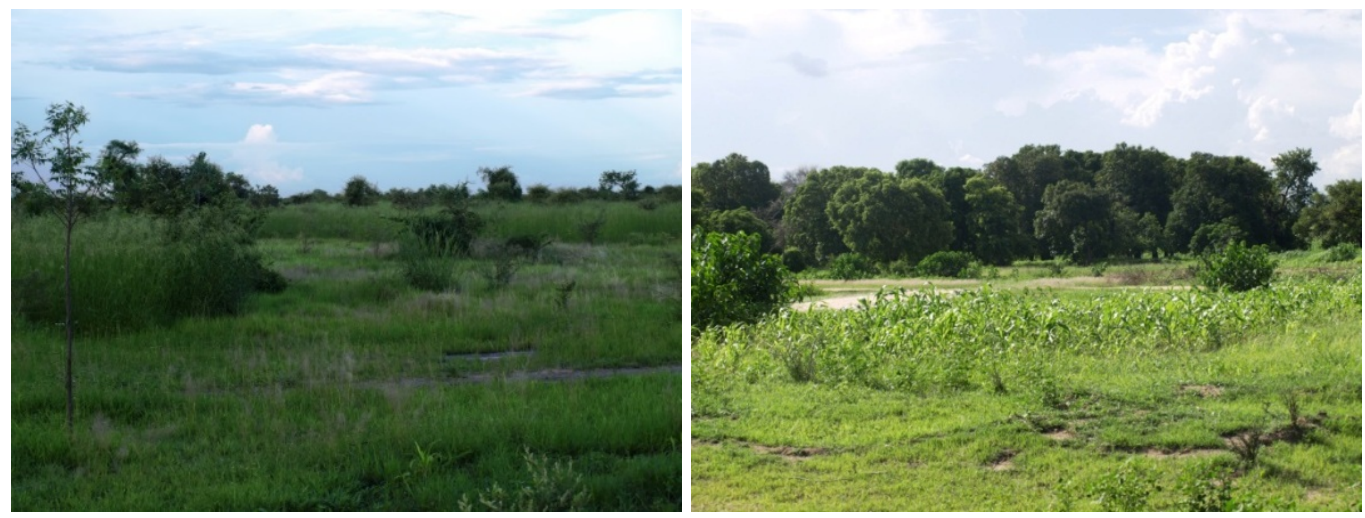

Figure 3. Kaélé afforestation sites (fieldwork, 2009-2012).

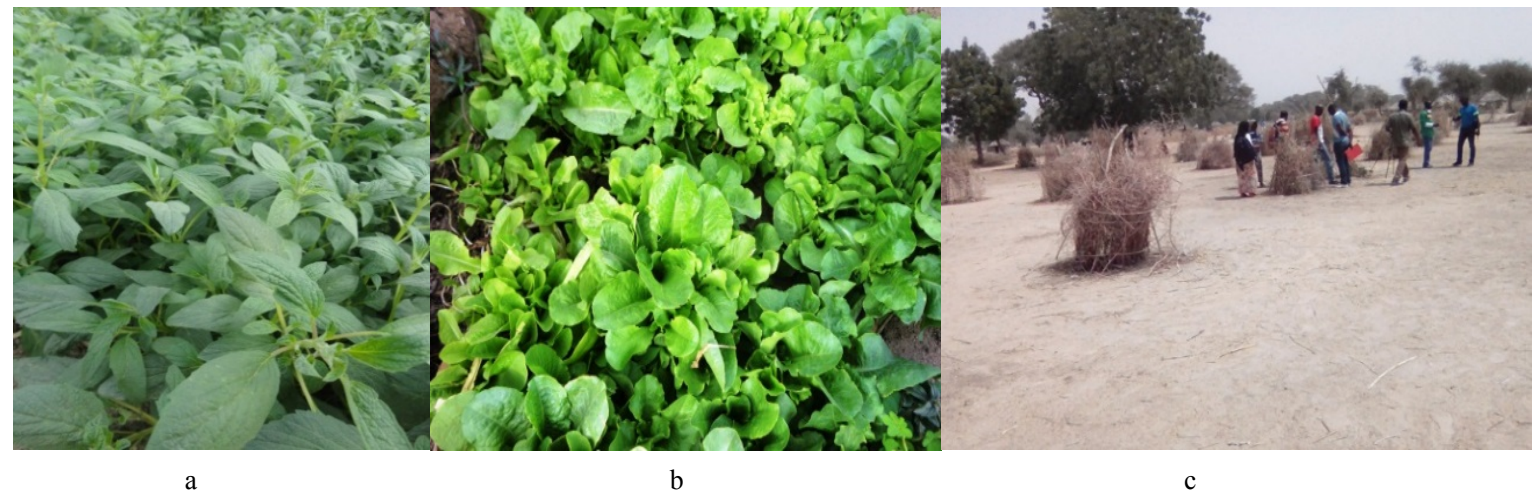

Figures 4. a, b: biological farming and organic gardening producing lettuce and vegetables in the dry season in the Sahel. c: Bedji Bedji School yard afforested (field work, 2016)

\subsection{EA, Climate Change and UNDP - COMDEKS Launching Strategies in Bogo}

In the Bogo landscape where the main environmental and social challenges associated with the landscape are linked to food insecurity resulting from climate variability and soil degradation; unsustainable agricultural and forestry practices that lead to soil erosion and crusting; a lack of sustainable livelihood options and women empowerment; recurrent health issues linked to a lack of clean drinking water and occurrence of extreme weather events; widespread poverty; and weak institutional capacity to support conservation and production. The production system in Bogo, similar to other Sahelian African production systems, is heavily dependent on rainfall: food crop production is mostly rain-fed and livestock rearing is through transhumance.

COMDEKS program was led between 2013 and 2016 by UNDP [35-36] through landscape analysis. It placed local communities at the center of adaptation strategies by using Satoyama initiative tools. On this aim, a landscape wide baseline assessment was conducted along with the Bogo communities in 2013 to assess the resilience of the landscape and to subsequently design a strategy intended to encourage practices strengthening resilience. As in the African Sahel, since the early 1970s, this vast plain has faced persistent drought that has resulted in shrinking resources and weakened food security [27]. The already low rainfall distribution is coupled with an intensification and increased unpredictability (with regard to duration and intensity) of droughts and rainfall over the past three decades (1972-1973 and 1983-1985), with a variability of rainfall of up to $40 \%-80 \%$. These droughts have resulted in the desiccation of crops and reduced yields, as well as superficial crusting leading to decreased soil fertility and more widespread poverty.

Consultation and participatory evaluation were conducted between September and October 2013 by a team of researchers, in compliance with social conventions in the far northern region of Cameroon. Following the landscape-wide baseline assessment, a landscape strategy was developed to address the key challenges identified. Based on the priority areas and challenges identified in the landscape strategy, seven community projects were implemented by civil society organizations (CSOs) in twelve communities in 2014. To address the various challenges and issues rose above, these community projects assessed in 2016 have provided local solutions to improve ecosystem and community resilience through the implementation of key resilience-strengthening activities as outlined in the landscape strategy. So the role of local communities and stakeholders was central in these adaptation strategies which results enable the re-greening of the Sahel and afforestation of the school yard by pupils (Figures $4 a-c$ ). 


\section{Discussion and Recommendations}

Overall, the above listed strategy documents have integrated adaptation to the various stages of the national policy cycle (policy formulation, planning, allocation and resource mobilization stakeholders identification and mobilization). Thus, SSA francophone countries ratified UNFCCC Convention, but, the climate change assessment parameters are not yet included in the these various countries legislation, resulting in a lack of legal constraints. However, best practices at the grassroots level help to fill this gap. This is the case with CPDev approach, which is integrative, participatory and flexible. Moreover, this tool really does not need standardized knowledge and it enables a strong ownership. It also improves the participation of vulnerable communities in valuing traditional knowledge and local know-how in spontaneous adaptation.

SEPL methods are also climate friend. SEPL and CPDev in agriculture entirely join the program launched at the COP 22 on the Adaptation of African Agriculture (AAA) to climate change. African Agriculture Adaptation initiative aims to reduce the vulnerability of Africa and its agriculture to climate change [37]. HELIO International also uses CPDev in improving energy systems and availability in SSA.

Conclusively, best practices in integrating EA into climate change adaptation lead decisively with certainty to the following aspects.

1) More resilient ecological agriculture with efficient and integrated agro-pastoral systems for food security.

2) More resilient agricultural and biophysical landscapes.

3) Better ecosystems protection and biodiversity conservation.

4) Fighting against desertification and regreening sahelian areas with availability of vegetables and fences to provide humidity.

5) More resilient and smart investments (not only in ecosystems services).

6) More resilient rural and urban economies.

7) Energy source diversification and production with best technologies.

8) Participatory energy governance bringing populations and beneficiaries to good ownership.

\section{Conclusions}

Environmental assessment appears to be a results-based process used by the developing countries governments to understand and evaluate the potential environmental impacts of many projects before any irreversible decisions are taken that may lead to negative effects on the environment, natural resources or public health and safety. Because of the complex and controversial nature of climate change and it evidence need for appropriate actions, it is recommended that it should be taken into consideration during the EA process. Biophysical and socio-economic impacts that aggravate existing development problems are: water shortages, floods, heat waves, biodiversity loss, electricity production shortage, population migration, population conflicts and health risks. The integration of EA tools and CPDev approach into planning is a real fact in SSA. Notwithstanding the existence of environmental regulation in each country, there is a lack of a permanent framework, integrating adaptation, including climate change law and regulations governing the coordination of institutions. Nevertheless, the establishment of climate change observatories in sub-Saharan francophone countries is also a good practice that supplements this regulation gap. Moreover, CPDev integration into the EA process becomes a successful story and effective substitute in African French speaking countries.

\section{REFERENCES}

[1] Werndl C. On Defining Climate and Climate Change, The British Journal for the Philosophy of Science, Volume 67, Issue 2, 1 June 2016, Pages 337-364,

https://doi.org/10.1093/bjps/axu048

[2] Frigg R., Thompson E. and Werndl C. Philosophy of Climate Science Part1: observing climate change Philosophy Compass 10/12 (2015): 953-964, $10.1111 / \mathrm{phc} 3.12294$

[3] UNFCCC, UNITED NATIONS FRAMEWORK CONVENTION ON CLIMATE CHANGE 1992.

[4] IPCC. Climate Change : The Physical Science Basis. Contribution of Working Group I to the Fifth Assessment Report of the Intergovernmental Panel on Climate Change. Cambridge and New York: Cambridge University Press, 2013.

[5] Solomon, S., Qin, D., Manning, M., Chen, Z., Marquis, M., Averyt, K. B., Tingor, M. and Miller, H. L. (2007). Climate Change 2007: The Physical Science Basis. Contribution of Working Group I to the Fourth Assessment Report of the Intergovernmental Panel on Climate Change. Cambridge: Cambridge University Press. (IPCC Report)

[6] Sircoulon J., Les données hydropluviométrique de la sècheresse récente en Afriqueintertropicale. Comparaison avec les sécheresses 1913 et 1940. Cah. ORSTOM (1976) sér. Hydr. XIII (2), 75, 174

[7] Servat, E., Paturel, J.-E., Lubes-Niel, H., Kouame, B., Masson, J.M., Travaglio, M. \& Marieu, B. De différents aspects de la variabilité de la pluviométrie en Afrique de l'ouest et centrale non sahélienne, Revue des sciences de l'eau, (1999) 12, 2, 363-387.

[8] IPCC, Climate Change, 2001a, The scientific basis. Contribution of Working Group I in The Third Assessment Report of the Intergovernmental Panel on Climate Change (eds Houghton JT, Ding Y, Griggs DJ, Noguer M, van der Linden PJ, Dai X, Maskell K, Johnson CA), Cambridge 
University Press, Cambridge, 881 pp.

[9] IPCC, Climate Change 2001b, Impact, adaptation and vulnerability. Contribution of Working Group II in The Third Assessment Report of the Intergovernmental Panel on Climate Change (eds James J. McCarthy, O F Canziani, NA Leary, DJ Dokken, K S. White).

[10] Hulme, M., Doherty, R., Ngara, T., New, M.\& Lister, D.: African climate change: 1900-2100. Climate Research (2001) 17 (2), 154-168.

[11] Nicholson, S.E and Grist, J.P.: A conceptual model for understanding rainfall variability in theWest African Sahel on interannual and interdecadal timescales. International Journal of Climatology (2001) 21 (14), 1733-1757.

[12] Tchindjang M., Amougou J.A., Abossolo S.A., Bessoh Bell S., Challenges of climate change, landscape dynamics and environmental risks in Cameroon. In Landscape Evolution, Neotectonics and Quaternary Environmental Change in Southern Cameroon. Palaeoecology of Africa, 31, Ch.5, (2012) 237-286.

[13] Bonnefille, R.: Evidence for a cooler and drier climate in Ethiopian Uplands towards 2.5 Myr ago, Nature 303 (1983) 487-491.

[14] Bonnefille, R., Potts, R., Chalié, F., Jolly, D. \& Peyron, D.O.: High resolution vegetation and climate change associated with Pliocene Australopithecus afarensis, Proc. Nat Acad. Sci. USA 101 (2004) 12125-12129.

[15] Gasse, F \& Van Campo, E.: Abrupt post-glacial climate events in West Asia and North Africa monsoon domains, Earth Planet. Sci. Lett. 126 (1994) 435-456.

[16] Gasse, F.: Hydrological changes in the African tropics since the Last Glacial Maximum, Quat. Sci. Rev. 19 (2000) 189211.

[17] Verschuren, D., Laird, K.R., \& Cumming, B.F.: Rainfall and drought in equatorial East Africa during the past 1100 years, Nature 403 (2000) 410-414.

[18] Tyson, P.D., Lee-Thorp, J., Holmgren, K. \& Thackeray, J.F.: Changing gradients of climate change in southern Africa during the past millennium: implications for population movements, Clim.Change (2002) 52, 129-135.

[19] Mahé G., Lerique J., Olivry J.C.: L'Ogooué au Gabon. Reconstitution des débits manquants et mise en évidence de variations climatiques à l'équateur. Hydrologie Continentale (1990), edn. ORSTOM, Paris, 5, 2, 105-124.

[20] Mahé G. \& Olivry J.C.: Changements climatiques et variations des écoulements en Afrique occidentale et centrale, du mensuel à l'interannuel. In: Hydrology for the water management of large river basins. F.H.M. Van de Ven, D. Gutknecht, D.P. Loucks \& K.A. Salewicz Eds, Congrès AISH, Vienne, Autriche, 13-15 août 1991, Publication AISH n²01 (1991). 163-172.

[21] Liénou G., Mahé G., Olivry J.C., Naah E., Servat E., Sigha-Nkamdjou L., Sighomnou D., Ndam Ngoupayou J., Ekodeck G.E. \& Paturel J.E.: Régimes des flux des matières solides en suspension au Cameroun : revue et synthèse à l'échelle des principaux écosystèmes ; diversité climatique et actions anthropiques. Hydrological Sciences Journal (2005) 50, 1, 111-124.
[22] Liénou, G.: Impacts de la variabilité climatique sur les ressources en eau et le transport des matières en suspension de quelques bassins versants représentatifs des unités climatiques au Cameroun. Thèse Doctorat, Université de Yaoundé I, Cameroun (2007).

[23] Liénou, G., Mahe, G., Paturel, J.E., Servat, E., Sighomnou, D., Ekodeck, G.E., Dezetter, A. \& Dieulin, C., 2008, Evolution des régimes hydrologiques en région équatoriale camerounaise: un impact de la variabilité climatique en Afrique équatoriale?. Hydrological Sciences-Journal-des Sciences Hydrologiques (2008), 53 (4); Pp789-801.

[24] CSC: Climate Change Scenarios for the Congo Basin. [Haensler A., Jacob D., Kabat P., Ludwig F. (eds.)]. Climate Service Centre Report No. 11, Hamburg, Germany, ISSN: 2192-4058; 2013.

[25] Achieng Ogola P. F. Environmental impact assessment general procedures. Presented at Short Course II on Surface Exploration for Geothermal Resources, organized by UNU-GTP and KenGen, at Lake Naivasha, Kenya, 2-17 November, 2007.

[26] UNU-IAS, Bioversity International, IGES and UNDP, Toolkit for the Indicators of Resilience in Socioecological Production Landscapes and Seascapes (SEPLS), United Nations University Institute for the Advanced Study of Sustainability, 2014, Tokyo, Japan.

[27] Tchindjang, M, Njombissie Petcheu, IC, Kamga Fogue, A, Nyemeck Mpeck, ML \& Chiewouo Kuetche, IF, 'La contribution de l'évaluation du Paysage à la sécurité alimentaire en zone sahélienne : le cas de Bogo dans l'Extrême Nord du Cameroun', Revue Scientifique et Technique Forêt et Environnement du Bassin du Congo (2015), Vol. 5, pp. 35-53

[28] Federal-Provincial-Territorial Committee on Climate Change and Environmental Assessment Incorporating Climate Change Considerations in Environmental Assessment: General Guidance for Practitioners. CEAA, 2003.

[29] Hahn M. and Fröde, A., Climate Proofing for Development. Adapting to Climate Change, Reducing Risk. GIZ, Eschborn, 2011.

[30] Dupoux P. and Zrikem Y., L'adaptation de l'agriculture africaine » est « une priorité. Journal Le Monde 09 /11 $/ 2016$.

[31] Amougou J.A., Tchindjang M.,. Abossolo S.A,. Batha R.A.S, A comparative study of the influence of climatic elements on cocoa production in to agrosystems of bimodal rainfall: case of Ngomedzap forest zone and the contact area of forest savanna of Bokito. Journal of Cameroon Academy of Sciences (JCAS) Vol. $11 N^{\circ} 1$ (2013) 27-37.

[32] WHO, Indoor Air Pollution: National Burden of Disease Estimates, 2007.

[33] Helio International, Climate proofing energy systems, 2009

[34] Ntsama Atangana J., Tchindjang M., Moulende T., Bene Bene C.L., Evaluation environnementale de la problématique de bois de feu dans la vile de Garoua Nord Cameroun (2010), available online at http://www.sifee.org/Actes/actes_paris_2010/Communicati ons/BLOC_4/S_4.1/3_NTSAMA_ATANGANA_TXT.pdf, 2010. 
[35] PNUD, Rapport de l'Évaluation ex-Post de la situation de référence du paysage du projet « Développement Communautaire et de Gestion de Connaissances pour l'Initiative Satoyama (COMDEKS) ». Arrondissement de Bogo, Région de l'Extrême-Nord, Cameroun. Yaoundé, 2016.

[36] Mpeck Nyemeck M.L., Kamga Fogue A.,Tchindjang M. and Zeh-Nlo M. The Bogo landscape in Cameroon drylands: contribution of local communities to adaptive management. In UNU-IAS \& IR3S/UTIAS 2016, Socio-ecological production landscapes and seascapes (SEPLS) in Africa. Chap .3 .United Nations University Institute for the Advanced Study of Sustainability, 2016. Tokyo, pp. 18-27

http://satoyama-initiative.org/wp-content/uploads/2016/08/ SEPLS-in-Africa_FINAL_lowres_web.pdf

[37] AAA, The Initiative for the 'Adaptation of African agriculture to Climate Change. AAA White paper, 2016. 